\section{Oxidant identity determines the As(III) removal pathway during treatment of groundwater rich in $\mathrm{As}(\mathrm{III}), \mathrm{Fe}(\mathrm{II})$ and $\mathrm{Mn}$ (II)}

\author{
CASE VAN GENUCHTEN ${ }^{1}$ AND ARSLAN AHMAD ${ }^{2,3}$ \\ ${ }^{1}$ Department of Geochemistry, Geological Survey of Denmark \\ and Greenland \\ ${ }^{2}$ KTH Royal Institute of Technology, Stockholm \\ ${ }^{3}$ Sibelco \\ Presenting Author: cvg@geus.dk
}

Effective methods to remove arsenic (As) from groundwater are needed in view of increasingly stringent As drinking water limits around the world. The oxidation of anoxic As(III)-rich groundwater, which often contains co-occurring $\mathrm{Fe}(\mathrm{II})$ and $\mathrm{Mn}(\mathrm{II})$, is one of the simplest groundwater treatment methods. In this method, an oxidant is introduced to convert aqueous Fe(II) to insoluble $\mathrm{Fe}(\mathrm{III})$ (oxyhydr)oxides that bind $\mathrm{As}$ and can be removed by filtration. While aeration is inexpensive, dosing $\mathrm{O}_{2}$ to As(III)-rich groundwater often cannot achieve low As levels because $\mathrm{O}_{2}$ alone cannot rapidly oxidize As(III) to the readilysorbed As(V) oxyanion. Therefore, water providers have proposed switching to strong oxidants to meet lower As limits.

This presentation will compare the addition of weak $\left(\mathrm{O}_{2}\right)$, intermediate $(\mathrm{NaOCl})$ and strong $\left(\mathrm{KMnO}_{4}\right)$ groundwater oxidants on the fate of As during $\mathrm{As}(\mathrm{III}), \mathrm{Fe}(\mathrm{II})$ and $\mathrm{Mn}(\mathrm{II})$ co-oxidation. Experiments were performed by dosing the oxidants with automated reactors to initially anoxic solutions containing 50 $\mu \mathrm{g} / \mathrm{L} \mathrm{As}(\mathrm{III}), 5 \mathrm{mg} / \mathrm{L} \mathrm{Fe}(\mathrm{II})$ and $0.5 \mathrm{mg} / \mathrm{L} \mathrm{Mn}(\mathrm{II})$ and relevant groundwater ions. The removal of As was quantified by ICP-MS and the solid reaction products were characterized by As, Fe and Mn K-edge X-ray absorption spectroscopy.

Our results showed that the oxidizing agent largely determined the pathways and efficiency of As removal. Adding $\mathrm{O}_{2}$ removed $\mathrm{Fe}(\mathrm{II})$, yielding $\mathrm{Mn}(\mathrm{III})$-incorporated lepidocrocite, but was unable to decrease As to $<10 \mu \mathrm{g} / \mathrm{L}$, which was attributed to inefficient $\mathrm{As}(\mathrm{III})$ oxidation. Dosing $\mathrm{NaOCl}$ consistently decreased As to $<10 \mu \mathrm{g} / \mathrm{L}$ (and often $<5 \mu \mathrm{g} / \mathrm{L}$ ), and removed $\mathrm{As}(\mathrm{III})$ via oxidation and $\mathrm{As}(\mathrm{V})$ sorption to co-precipitated $\mathrm{Mn}$ (III)-rich hydrous ferric oxide (HFO) in the binuclear, bridging $\left({ }^{2} \mathrm{C}\right)$ complex. The addition of $\mathrm{KMnO}_{4}$ removed $\mathrm{As}(\mathrm{III})$ most effectively, yielding lower residual As concentrations (by as much as $50 \%$ ) than the $\mathrm{NaOCl}$ experiments. The enhanced As removal with $\mathrm{KMnO}_{4}$ coincided with a systematically shorter As-metal bond length in the solids $\left(\mathrm{R}_{\mathrm{As}-\mathrm{Fe} / \mathrm{Mn}}=3.24 \pm 0.02 \AA\right)$ compared to $\mathrm{NaOCl}$ addition $\left(\mathrm{R}_{\mathrm{As}-\mathrm{Fe} / \mathrm{Mn}}=3.29 \pm 0.02 \AA\right)$, consistent with $\mathrm{As}(\mathrm{V})$ sorption to both $\mathrm{HFO}$ and $\mathrm{MnO}_{2}$ produced from $\mathrm{KMnO}_{4}$ reduction. The implications of these results will be discussed in the context of optimizing groundwater treatment to meet stringent As limits while also considering particle suspension characteristics (i.e. colloidal stability).

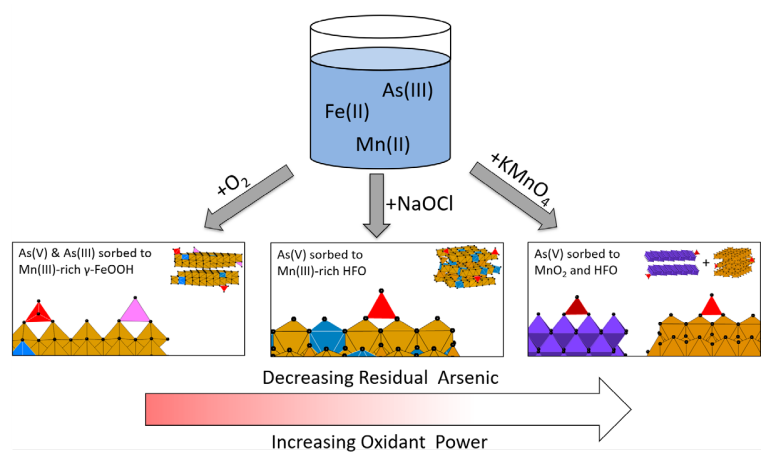

